\title{
The Action of Ultrasonic Vibrations on Actinophages
}

\author{
By D. L. ANDERSON AND S. G. BRADLEY \\ Department of Microbiology, University of Minnesota, Minneapolis, U.S.A.
}

(Received 28 April 1964)

SUMMARY

High-frequency sonic oscillations destroyed the plaque-forming ability of actinophages. Among the $\mathbf{3 1}$ actinophage strains studied, the fraction of viral particles which survived an exposure for $1 \mathrm{~min}$. to vibrations of 20 kcyc. $/$ sec. varied from 100 to $\mathbf{0 . 0 0 0 2} \%$. Coliphage T2hr + was more susceptible to ultrasonic treatment than were some actinophages and was more resistant than other actinophages. In general, large actinophage particles were more sensitive to sonic treatment than small particles. A 60 W. $20 \mathrm{kcyc}$. $/ \mathrm{sec}$. M.S.E. Ultrasonic Disintegrator destroyed actinophages more rapidly than a 50 W., 9 kcyc./sec. Raytheon Sonic Oscillator. Electron micrographs of actinophage MSP8 treated with sonic vibrations showed progressive disruption of the viral particles. Susceptibility to sonic inactivation gave an additional criterion for grouping actinophages.

\section{INTRODUCTION}

Ultrasonic oscillations produced by vibrating crystals or diaphragms have been shown to inactivate various types of bacteriophages suspended in liquid media (Anderson, Boggs \& Winters, 1948; Beumer \& Beumer-Jochmans, 1950; Fadeeva, Rautenshtein \& El'piner, 1959). Anderson and co-workers reasoned that if bacteriophages were more resistant to sonic vibration than were their hosts, early stages of phage multiplication could be studied by sonically-disrupting bacteria at intervals after infection. Anderson \& Doermann (1952) used this method in studies on the intracellular development of coliphage T3. Beumer \& Beumer-Jochmans (1950) found large differences in the sensitivities of staphylococcus phage 'Twort' and coliphages PF and pfi, to sonic vibrations of $1000 \mathrm{kcyc} . / \mathrm{sec}$. Fadeeva et al. (1959) found a phage of Bacillus megaterium to be much more sensitive to oscillations at a frequency of about $650 \mathrm{kcyc}$./sec. than were phages virulent for Actinomyces olivaceus (Streptomyces olivaceus) and Actinomyces streptomycini (Streptomyces griseus). Hydrogen and argon atmospheres had no protective effect against the inactivation of the $B$. megaterium phage.

We wished to determine whether ultrasonic treatment could be used to prepare actinophage 'ghosts', to separate phage heads from tails, and to determine whether actinophages with similar host ranges had similar sensitivities to sonic treatment. Susceptibility to ultrasonic vibrations has been generally correlated with other criteria for classifying actinophages. Electron microscopic examination of treated actinophage suspensions showed that mechanical disruption was correlated with loss of plaque-forming ability. 


\section{METHODS}

Actinophages. The actinophages used and their hosts are given in Table 1. The origins of these actinophages were recorded previously (Anderson, 1961).

Actinophages were grown on the appropriate host in a medium composed of: $5 \mathrm{~g}$. Difco peptone; $3 \mathrm{~g}$. Difco yeast extract; $0.5 \mathrm{~g}$. $\mathrm{Ca}\left(\mathrm{NO}_{3}\right)_{2}$; per litre of de-ionized water. The methods used for propagating and assaying the actinophages were described by Bradley, Anderson \& Jones (1961). Phage lysates were filtered through unglazed porcelain filters to remove host debris, and the filtrates stored at $4^{\circ}$.

Ultrasonic treatments. Filtered phage suspensions were subjected to 18-20 kcyc./ sec. generated by a 60 W. M.S.E. Ultrasonic Disintegrator (Measuring and Scientific Equipment Ltd., London) or to 9 kcyc./sec. from the 50 W. Model S102A Raytheon Oscillator (Raytheon Manufacturing Company, Waltham, Massachusetts, U.S.A.). Containers holding $10 \mathrm{ml}$. of phage suspension were immersed in an ice bath during the $12 \mathrm{~min}$. treatment period. Samples $(0.3 \mathrm{ml}$.) were removed at intervals; the numbers of infectious particles were enumerated on peptone yeast-extract agar by the soft agar overlay method (Jones \& Bradley, 1962).

Electron microscopy. Suspensions of actinophage MSP8 to be observed by electron microscopy were purified on columns of G-75 coarse Sephadex (Pharmacia, Uppsala, Sweden) and ECTEOLA-cellulose (Bio-Rad Corp., Richmond, Calif., U.S.A.) or by several cycles of centrifugation (Kolstad \& Bradley, 1964). Treated suspensions were dried on Formvar-coated specimen grids, shadowed with uranium, and observed in an RCA EMU-3F electron microscope.

\section{RESULTS \\ Effects on infectivity}

Actinophages markedly lost infectivity as measured by plaque forming ability when subjected to ultrasonic oscillations of $18-20 \mathrm{kcyc}$. $/ \mathrm{sec}$. or $9 \mathrm{kcyc}$./sec. for various periods (Tables 1 and 2). The actinophage strains differed substantially in sensitivity to ultrasonic treatment. For example, $10 \%$ of the infective units of phages MSP 8, WSP1, and WSP3 survived 12 min. ultrasonic treatment, whereas the infective titre of other actinophages (e.g. MSP 11) decreased from $10^{8}$ particles/ $\mathrm{ml}$. to undetectable values after treatment for $2 \mathrm{~min}$. Coliphage $\mathrm{T} 2 \mathrm{hr}+$ was more sensitive to ultrasonic treatment than were some of the actinophages and was more resistant than others. A comparison of phage inactivation produced by the M.S.E. Disintegrator (Table 1) and by the Raytheon Oscillator (Table 2) suggested that the former instrument was more effective. The M.S.E. apparatus destroyed more than 10 times as many particles of coliphage $\mathrm{T} 2 \mathrm{hr}+$ as did the Raytheon apparatus after treatment for 2 min., about 100 times as many particles after $4 \mathrm{~min}$., and about 1000 times as many particles after $12 \mathrm{~min}$. Similar results were obtained in comparing the susceptibilities of actinophages MNP8 and WSP3 to treatment in these two instruments.

To determine the effect of the initial phage concentration on the inactivation rate, the initial concentration of several phage suspensions was adjusted so that their titres differed by factors of 10 to 1000 . In general, the rate of inactivation of separate suspensions of a particular phage was independent of initial phage concentration (Table 3). 
For those actinophages whose size had been determined, large phages proved more sensitive to ultrasonic treatment than small phages. For example, actinophages MSP 19, MNP 8, MNP6, all of which were quickly inactivated by ultrasonic treat-

Table 1. The effects of ultrasonic treatment at $20 \mathrm{kcyc} . / \mathrm{sec}$. on the infectivity of various actinophages and coliphage $T 2 h r+$

\begin{tabular}{|c|c|c|c|c|c|c|c|c|}
\hline \multirow[b]{2}{*}{ Phage } & \multirow[b]{2}{*}{ Host } & \multirow{2}{*}{$\begin{array}{c}\text { Log. } \\
\text { initial } \\
\text { titre }\end{array}$} & \multicolumn{6}{|c|}{$\begin{array}{c}\text { Log. } \frac{\text { Initial phage titre }}{\text { Phage titre after }} \\
\text { ultrasonic treat- } \\
\text { ment for (min.) }\end{array}$} \\
\hline & & & 0.25 & $\mathbf{1}$ & 2 & 4 & 7 & 12 \\
\hline MSP 8 & Streptomyces venezuelae $\mathrm{S} 13$ & $8 \cdot 8$ & $0 \cdot 1$ & 0.3 & $0 \cdot 4$ & 0.5 & 0.7 & $1 \cdot 0$ \\
\hline MSP 8 & S. griseus S 104 & $4 \cdot 4$ & $-0 \cdot 1$ & 0.1 & $0 \cdot 1$ & 0.4 & $\mathbf{0} \cdot \mathbf{3}$ & 0.6 \\
\hline MSP 1 & S. griseus S 86 & $9 \cdot 0$ & 0.2 & 0.8 & $\mathbf{2 \cdot 6}$ & $3 \cdot 5$ & $3 \cdot 5$ & $3 \cdot \mathbf{6}$ \\
\hline MSP2 & S. griseus S86 & $7 \cdot 7$ & $0 \cdot 2$ & 0.3 & $0 \cdot 4$ & $0 \cdot 8$ & $1 \cdot 3$ & $1 \cdot 2$ \\
\hline WSPI & S. griseus $\mathrm{S} 86$ & $7 \cdot 8$ & $-0 \cdot 1$ & $-0 \cdot 2$ & $0 \cdot 1$ & $0 \cdot 2$ & 0.6 & $1 \cdot 1$ \\
\hline WSP3 & S. griseus $\mathrm{S} 104$ & $6 \cdot 3$ & -0.2 & $-0 \cdot 1$ & $0 \cdot 2$ & $0 \cdot 1$ & 0.5 & $1 \cdot 1$ \\
\hline MSP7 & S. violaceoruber $\mathbf{S} 199$ & $8 \cdot 3$ & $0 \cdot 4$ & $1 \cdot 3$ & $2 \cdot 8$ & 4.5 & $5 \cdot 7$ & $5 \cdot 8$ \\
\hline MSP 11 & S. violaceoruber $\mathrm{S} 199$ & $8 \cdot 1$ & $\mathbf{2 \cdot 6}$ & $4 \cdot 3$ & - & - & - & - \\
\hline MSP 15 & S. violaceoruber $\mathrm{S} 199$ & $7 \cdot 5$ & 0.7 & $2 \cdot 4$ & $4 \cdot 3$ & $5 \cdot 1$ & 6.5 & $6 \cdot 0$ \\
\hline MSP 16 & S. violaceoruber $\mathrm{S} 199$ & $7 \cdot 2$ & 1.5 & $\mathbf{2 \cdot 8}$ & $\mathbf{3} \cdot \mathbf{4}$ & $3 \cdot 6$ & $6 \cdot 2$ & - \\
\hline MSP 17 & S. violaceoruber $\mathbf{S} 199$ & $7 \cdot 7$ & $\mathbf{2 \cdot 3}$ & $\mathbf{3 \cdot 7}$ & $4 \cdot 2$ & - & - & - \\
\hline MSP 18 & S. violaceoruber $S 199$ & $9 \cdot 4$ & $1 \cdot 6$ & $\mathbf{3} \cdot \mathbf{0}$ & $4 \cdot 1$ & $5 \cdot 1$ & $6 \cdot 2$ & $6 \cdot 4$ \\
\hline MSP 19 & S. violaceoruber $\mathbf{S} 199$ & $7 \cdot 0$ & $4 \cdot 0$ & $5 \cdot 3$ & 一 & - & - & - \\
\hline MSP21 & S. vinaceus S208 & $8 \cdot 0$ & $1 \cdot 0$ & $\mathbf{2 \cdot 3}$ & 3.9 & $3 \cdot 7$ & $4 \cdot 1$ & 5.8 \\
\hline MSP 22 & S. vinaceus S208 & $\mathbf{7 . 9}$ & $1 \cdot 3$ & $3 \cdot 1$ & $4 \cdot 5$ & - & - & - \\
\hline MNP4 & S. griseus $\mathrm{S} 104$ & $9 \cdot 4$ & 1.0 & $2 \cdot 4$ & $\mathbf{3 . 9}$ & 4.7 & - & - \\
\hline MNP3 & S. griseus $\mathrm{S} 104$ & $9 \cdot 6$ & $0 \cdot 3$ & $1 \cdot 1$ & $\mathbf{2 \cdot 3}$ & $2 \cdot 6$ & $3 \cdot 5$ & $4 \cdot 4$ \\
\hline MVP4 & S. cinnamomeus 1285 & $\mathbf{7 \cdot 7}$ & 0.5 & $1 \cdot 6$ & $\mathbf{3 \cdot 2}$ & $4 \cdot 3$ & 4.7 & $6 \cdot 7$ \\
\hline MNP1 & Nocardia brasiliensis N 301 & $6 \cdot 8$ & $0 \cdot 4$ & 0.5 & $1 \cdot 3$ & $2 \cdot 4$ & $4 \cdot 4$ & $4 \cdot 6$ \\
\hline MNP2 & N. brasiliensis $\mathbf{N} 301$ & $7 \cdot 3$ & $\mathbf{2 \cdot 3}$ & $3 \cdot 2$ & 3.9 & $4 \cdot 1$ & - & - \\
\hline MNP6 & N. brasiliensis N 301 & 7.7 & 0.2 & $0 \cdot 7$ & $\mathbf{2 \cdot 2}$ & 3.7 & $4 \cdot 2$ & $6 \cdot 4$ \\
\hline MNP7 & N. brasiliensis N301 & $8 \cdot 1$ & $0 \cdot 6$ & $\mathbf{2 \cdot 3}$ & $\mathbf{3 \cdot 5}$ & 4.9 & $5 \cdot 9$ & $6 \cdot 2$ \\
\hline MMP 1 & N. brasiliensis N301 & $6 \cdot 2$ & $0 \cdot 4$ & $0 \cdot 1$ & $2 \cdot 2$ & - & - & - \\
\hline MJP1 & Jensenia canicruria $1574 \mathrm{~L}$ & 8.9 & $0 \cdot 8$ & $2 \cdot 1$ & $\mathbf{3} \cdot \mathbf{0}$ & 3.7 & $4 \cdot 7$ & $5 \cdot 3$ \\
\hline MMP9 & Mycobacterium sp. A405 & $5 \cdot 6$ & $0 \cdot 2$ & 1.7 & - & 4.2 & - & - \\
\hline MMP 14 & M. friburgensis A 403 & $5 \cdot 5$ & $1 \cdot 0$ & $\mathbf{2} \cdot \mathbf{2}$ & $4 \cdot 8$ & - & - & - \\
\hline MMP13 & M. friburgensis A403 & $5 \cdot 1$ & 0.6 & $1 \cdot 9$ & 4.1 & - & - & - \\
\hline MMP 8 & M. rabinoreitsch A 402 & $4 \cdot 1$ & $1 \cdot 1$ & $3 \cdot 4$ & - & - & 一 & - \\
\hline MMP10 & M. stercoides A 406 & 6.9 & 0.9 & $2 \cdot 1$ & $4 \cdot 1$ & $3 \cdot 7$ & $\mathbf{3 \cdot 9}$ & - \\
\hline MMP7 & M. rabinowitsch A 402 & 6.9 & 4.0 & $5 \cdot 7$ & - & - & - & - \\
\hline T2hr+ & Escherichia coli B & $9 \cdot 0$ & $0 \cdot 1$ & $0 \cdot 4$ & $1 \cdot 4$ & $\mathbf{3 \cdot 3}$ & $4 \cdot 5$ & $5 \cdot 4$ \\
\hline T2hr+ & E. coli B & $9 \cdot 1$ & $0 \cdot 1$ & $0 \cdot 4$ & $1 \cdot 2$ & 3.0 & 4.9 & $\mathbf{5} \cdot 2$ \\
\hline
\end{tabular}

Table 2. The effects of ultrasonic treatment at $9 \mathrm{kcyc} . / \mathrm{sec}$. on the infectivity of various actinophages and coliphage $\mathrm{T} 2 \mathrm{hr}+$

\begin{tabular}{|c|c|c|c|c|c|c|c|c|c|}
\hline \multirow[b]{2}{*}{ Phage } & \multirow[b]{2}{*}{ Host } & \multirow{2}{*}{$\begin{array}{c}\text { Log. } \\
\text { initial } \\
\text { titre }\end{array}$} & \multicolumn{5}{|c|}{ 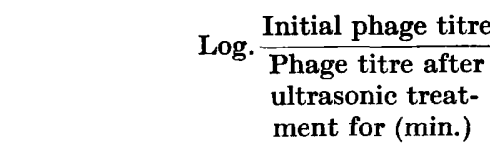 } & \multirow[b]{2}{*}{27} & \multirow[b]{2}{*}{57} \\
\hline & & & 0.5 & 2 & 4 & 7 & 12 & & \\
\hline WSP3 & $\begin{array}{l}\text { Streptomyces griseus } \\
\text { S104 }\end{array}$ & $8 \cdot 2$ & - & - & - & 0.2 & $0 \cdot 4$ & 0.5 & 0.6 \\
\hline MNP8 & $\begin{array}{l}\text { Nocardia corallina } \\
\text { W5 }\end{array}$ & $5 \cdot 2$ & $-0 \cdot 3$ & 0.9 & $\mathbf{2 \cdot 3}$ & - & $4 \cdot 2$ & 4.2 & - \\
\hline $\mathrm{T} 2 \mathrm{hr}+$ & Escherichia coli B & $9 \cdot 1$ & $-0 \cdot 1$ & -0.1 & 0.9 & $0 \cdot 7$ & $1 \cdot 8$ & $\mathbf{3 \cdot 7}$ & $4 \cdot 4$ \\
\hline
\end{tabular}


ment, were longer than $300 \mathrm{~m} \mu$ and had head dimensions of about 70-80 $\mathrm{m} \mu$ (Anderson, 1961). Conversely, actinophages MSP2, WSP1, WSP 3, which were highly resistant to ultrasonic treatment, were all about $250 \mathrm{~m} \mu$ in overall length. Actinophages WSP1 and WSP3 had head dimensions of less than $60 \mathrm{~m} \mu$.

Table 3. The effects of initial phage concentration on the ultrasonic inactivation rate Ultrasonic treatment by a 20 kcyc./sec. M.S.E. instrument.

\begin{tabular}{|c|c|c|c|c|c|c|c|c|}
\hline \multirow[b]{2}{*}{ Phage } & \multirow[b]{2}{*}{ Host } & \multirow{2}{*}{$\begin{array}{c}\text { Log. } \\
\text { initial } \\
\text { titre }\end{array}$} & \multirow[b]{2}{*}{0.25} & \multirow{2}{*}{$\begin{array}{l}\log \\
1\end{array}$} & \multicolumn{4}{|c|}{$\begin{array}{l}\text { Initial phage titre } \\
\text { Phage titre after } \\
\text { ultrasonic treat- } \\
\text { ment for (min.) }\end{array}$} \\
\hline & & & & & $\mathbf{2}$ & 4 & 7 & 12 \\
\hline MSP 10 & S. violaceoruber S199 & $6 \cdot 6$ & 0.2 & $1 \cdot 0$ & 3.4 & $4 \cdot 3$ & 一 & 一 \\
\hline MSP 10 & S. violaceoruber $\mathbf{S 1 9 9}$ & $5 \cdot 6$ & 0.5 & $\mathbf{1} \cdot \mathbf{3}$ & $\mathbf{2 \cdot 7}$ & $4 \cdot 6$ & $4 \cdot 6$ & - \\
\hline MNP 8 & N. corallina W5 & $7 \cdot 9$ & 0.9 & $2 \cdot 7$ & $5 \cdot 0$ & $6 \cdot 4$ & - & - \\
\hline MNP 8 & N. corallina W5 & $4 \cdot 8$ & $1 \cdot 0$ & $\mathbf{8} \cdot \mathbf{1}$ & - & - & - & - \\
\hline
\end{tabular}

Table 4. The relationship between mechanical disintegration of actinophage MSP 8 and loss of plaque-forming ability

\begin{tabular}{|c|c|c|c|c|c|c|c|}
\hline $\begin{array}{c}\text { Min. of } \\
\text { treatment }\end{array}$ & $\begin{array}{l}\text { Log. plaque } \\
\text { forming units }\end{array}$ & $\begin{array}{c}\text { Total } \\
\text { heads } \\
\text { (no.) }\end{array}$ & $\begin{array}{c}\text { Whole } \\
\text { phage } \\
(\%)\end{array}$ & $\begin{array}{c}\text { Phage } \\
\text { with } \\
\text { broken } \\
\text { heads } \\
(\%)\end{array}$ & $\begin{array}{c}\text { Whole } \\
\text { detached } \\
\text { heads } \\
(\%)\end{array}$ & $\begin{array}{c}\text { Broken } \\
\text { detached } \\
\text { heads } \\
(\%)\end{array}$ & $\begin{array}{c}\text { Whole } \\
\text { free } \\
\text { tails } \\
\text { (no.) }\end{array}$ \\
\hline 0 & 9.9 & 155 & 95 & $\mathbf{3}$ & - & 2 & 6 \\
\hline 0.5 & $9 \cdot 8$ & 212 & 83 & 15 & - & 1 & 29 \\
\hline 2 & $9 \cdot 7$ & 194 & 64 & 9 & 2 & 25 & 34 \\
\hline 4 & $9 \cdot 5$ & 542 & 51 & 8 & - & 41 & 106 \\
\hline 7 & Undetermined & 162 & 49 & 7 & 1 & 44 & 56 \\
\hline 12 & $8 \cdot 7$ & 294 & 31 & 6 & - & 62 & 142 \\
\hline 22 & $8 \cdot 3$ & 227 & 7 & 2 & 8 & 83 & 90 \\
\hline 42 & 7.7 & 121 & 3 & 1 & $\mathbf{8}$ & 95 & 56 \\
\hline
\end{tabular}

\section{Effects on structure}

Samples for electron-microscope examination were taken at intervals during ultrasonic treatment of actinophage MSP 8, and the frequencies of whole particles, particles with broken heads, broken detached heads, and whole detached heads were determined (Table 4). Almost all the viral particles of the untreated control were found to be intact (Fig. 1). After a short period of treatment, some phage heads were broken and separated from their tails; other particles appeared to be undisturbed (Pl. 1, figs. 2, 3). As the treatment progressed, more particles were disrupted; after $42 \mathrm{~min}$. of ultrasonic treatment no intact particles were found (Pls. 1, 2, figs. 4-8). Electron micrographs at this point showed masses of debris which included short tail fragments.

\section{DISCUSSION}

Fadeeva et al. (1959) showed that actinophages were inactivated by ultrasonic treatment at a frequency of about $650 \mathrm{kcyc}$. $/ \mathrm{sec}$. Treatments of $45 \mathrm{~min}$. to $6 \mathrm{hr}$. produced large decreases in infective titres. In the present work, exposure to ultrasonic treatment at a frequency of 18-20 kcyc./sec. for 1-12 min. caused a comparable loss of infectivity. Moreover, $20 \mathrm{kcyc}$./sec. was more effective in destroying the infec- 
tivity of the phages studied than a frequency of about 9 kcyc./sec. The $650 \mathrm{kcyc}$./ sec. treatment used by Fadeeva et al. (1959) apparently was not as effective in destroying actinophages as our $20 \mathrm{kcyc}$./sec. treatment; but meaningful comparisons cannot be made because their actinophages may have been quite different from those we studied. Moreover, our results cannot be compared directly with those of Beumer \& Beumer-Jochmans (1950), who used a $120 \mathrm{~W}$. instrument with a frequency of $1000 \mathrm{kcyc} . / \mathrm{sec}$. The intensity and the frequency of oscillation are undoubtedly both important factors in the destructive action of any ultrasonic treatment.

Anderson et al. (1948) suggested that small phages such as coliphage T3 probably escape the destructive cavitation which disrupts the larger phages such as coliphages T 2, T 4 and T6. In the present work, actinophages WSP 1, WSP3 and MSP 2 were inactivated less rapidly than the smaller coliphage T2hr + (overall length $190 \mathrm{~m} \mu$ ). The head of coliphage $\mathrm{T} 2 \mathrm{hr}+$, however, is about $95 \mathrm{~m} \mu$ long which is larger than the actinophage head structure. This suggests that susceptibility to ultrasonic treatment may be primarily dependent upon the dimensions of the head. Consistent with this view are the observations that coliphage $\mathbf{T} 5$ is far more susceptible to ultrasonic treatment than is coliphage $T 1$ and that the head of coliphage T5 $(65 \mathrm{~m} \mu)$ is larger than the head of coliphage T $1(50 \mathrm{~m} \mu)$. The tails of coliphages T5 and T1 are of about the same length (170 $\mathrm{m} \mu$ and $150 \mathrm{~m} \mu$, respectively; Stent, 1963).

Mechanism of ultrasonic inactivation of actinophage MSP8. Electron-microscope examination of samples of an ultrasonically treated suspension of actinophage MSP8 taken at intervals showed that mechanical disruption was important in inactivation (Pls. 1, 2, figs. 1-8). No sharp sequence of destructive events was detected (for example, breaking of heads, separation of heads from tails, fragmentation of tails). Tails, however, did not appear to fragment extensively until the ultrasonic treatment was prolonged from 22 to $42 \mathrm{~min}$. (Pl. 2, figs. 6, 7). Free tails consistently clumped after prolonged treatment ( $\mathrm{Pl} .2$, fig. 8). If the time of irradiation were controlled, it might be possible to separate intact actinophage tails from the phage heads, and then purify each component by appropriate physical techniques.

Taxonomic implications. One of the objects of this work was to determine whether ultrasonic treatment data would provide one more criterion in grouping actinophages. The sensitivity pattern of actinophages to ultrasonic treatment agrees in general with the classification based upon host range (Bradley et al. 1961). For example, actinophages MSP15, MSP16, MSP 17, MSP18, MSP19, which are closely related in host range, are all markedly susceptible to ultrasonic treatment. Similarly, actinophages WSP1 and WSP 3, which are quite resistant to ultrasonic treatment, are indistinguishable in host range. Adams (1959) stated that one of the major objections to the use of inactivation of any type of phage as a taxonomic criterion is that phage strains often differ quantitatively rather than qualitatively; indeed, there is limited diversity in sensitivity among members of a group with similar host ranges. When the sensitivities of different groups are compared, there is overlapping in ranges of variation among the groups. Obviously no one type of inactivation can be used as a sole taxonomic criterion; inactivation characteristics should be correlatable with other criteria, such as morphology and serology.

This investigation was supported by a research grant AI-01601 from the National Institute of Allergy and Infectious Diseases, U.S. Public Health Service. 


\section{REFERENCES}

Adams, M. H. (1959). Bacteriophages. New York and London: Interscience Publishers.

Anderson, D. L. (1961). Studies on actinophage. Ph.D. Thesis, University of Minnesota, Minneapolis, U.S.A.

Anderson, T. F., Boggs, S. \& Winters, B. C. (1948). The relative sensitivities of bacterial viruses to intense sonic vibration. Science, $108,18$.

Anderson, T. F. \& Doermann, A. H. (1952). The intracellular growth of bacteriophages. II. The growth of $\mathbf{T} 3$ studied by sonic disintegration and by $\mathbf{T}$-cyanide lysis of infected cells. J. gen. Physiol. 35, 657.

Beumer, J. \& Beumer-Jochmans, M. P. (1950). Étude du comportment aux ultrasons des bactériophages fixés sur les bactéries sensibles. Ann. Inst. Pasteur, 79, 860.

Bradley, S. G., Anderson, D. L. \& Jones, L. A. (1961). Phylogeny of actinomycetes as revealed by actinophage susceptibility. Develop. indust. Microbiol. 2, 223.

Fadeeva, N. P., Rautenshtein, Ya. I. \& El'Piner, I. E. (1959). Effect of ultrasonic waves on some actinophages and bacteriophages. Microbiology (A.I.B.S. translation of Mikrobiologiya), 28, 368.

Jones, L. A. \& Bradley, S. G. (1962). Relationship of Streptoverticillium and Jensenia to other actinomycetes. Develop. indust. Microbiol. 3, 257.

Kolstad, R. A. \& Bradley, S. G. (1964). Purification of Streptomyces venezuelae phage MSP 8. J. Bact. 87, 1157.

Stent, G. S. (1963). Molecular Biology of Bacterial Viruses. San Francisco and London: W. H. Freeman and Company.

\section{EXPLANATION OF PLATES}

Prate 1

Fig. 1. Untreated particles of actinophage MSP8; $\times 25,000$.

Fig. 2. Actinophage MSP 8 treated with 20 kcyc./sec. ultrasonic vibrations for $30 \mathrm{sec}$; $\times 25,000$.

Fig. 3. Actinophage MSP 8 after 4 min. treatment; $\times 25,000$.

Fig. 4. Actinophage MSP 8 after 7 min. treatment; $\times 26,818$.

\section{Plate 2}

Fig. 5. Actinophage MSP8 particles and debris after 12 min. treatment; $\times 25,000$.

Fig. 6. Actinophage MSP 8 particles and debris after $22 \mathrm{~min}$. treatment; $\times 25,000$.

Fig. 7. Head coats and debris from actinophage MSP 8 particles after 42 min. treatm ent; $\times 25,000$.

Fig. 8. Large clump of tails apparently held together by debris from actinophage MSP 8 particles after $42 \mathrm{~min}$. treatment; $\times 25,000$. 

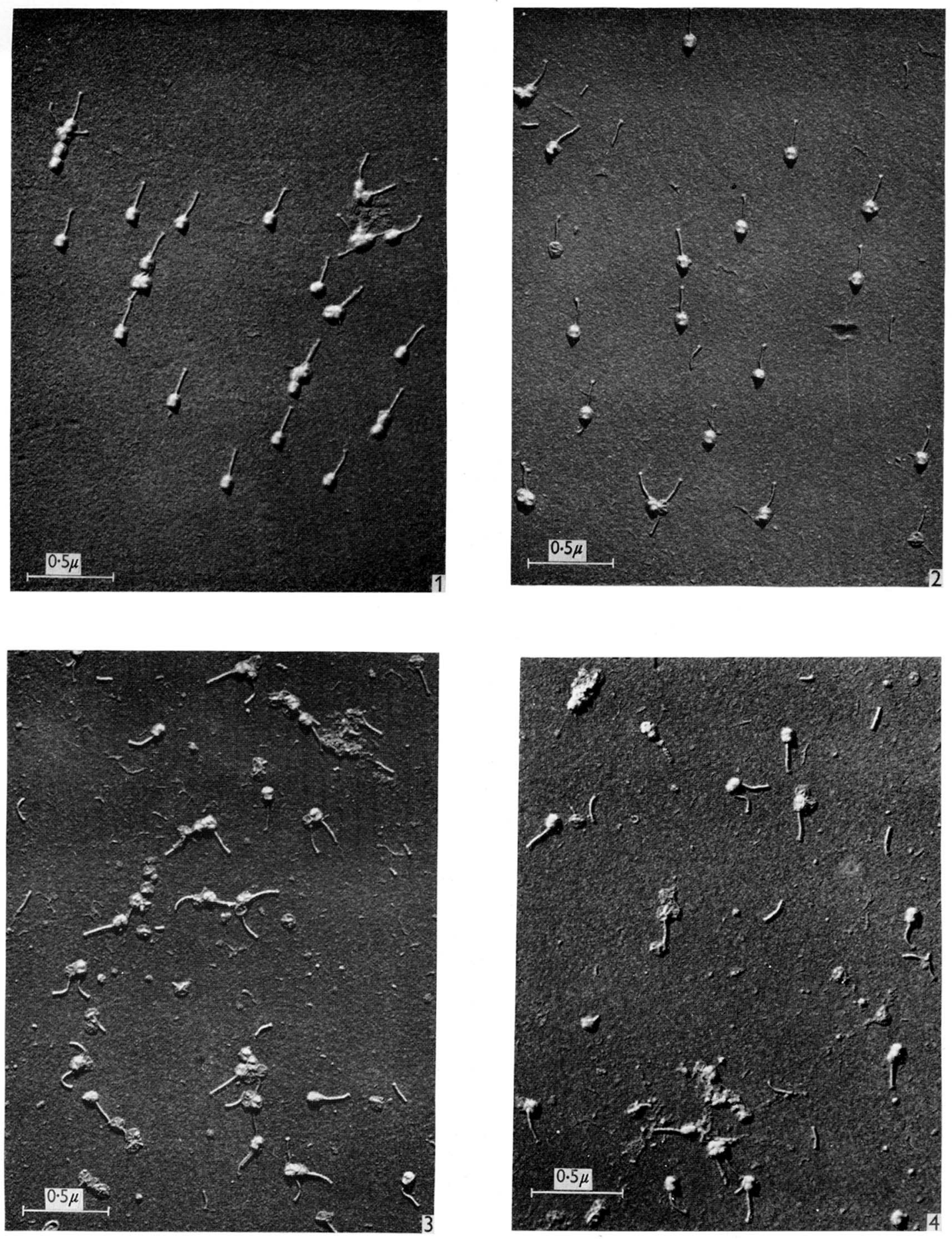

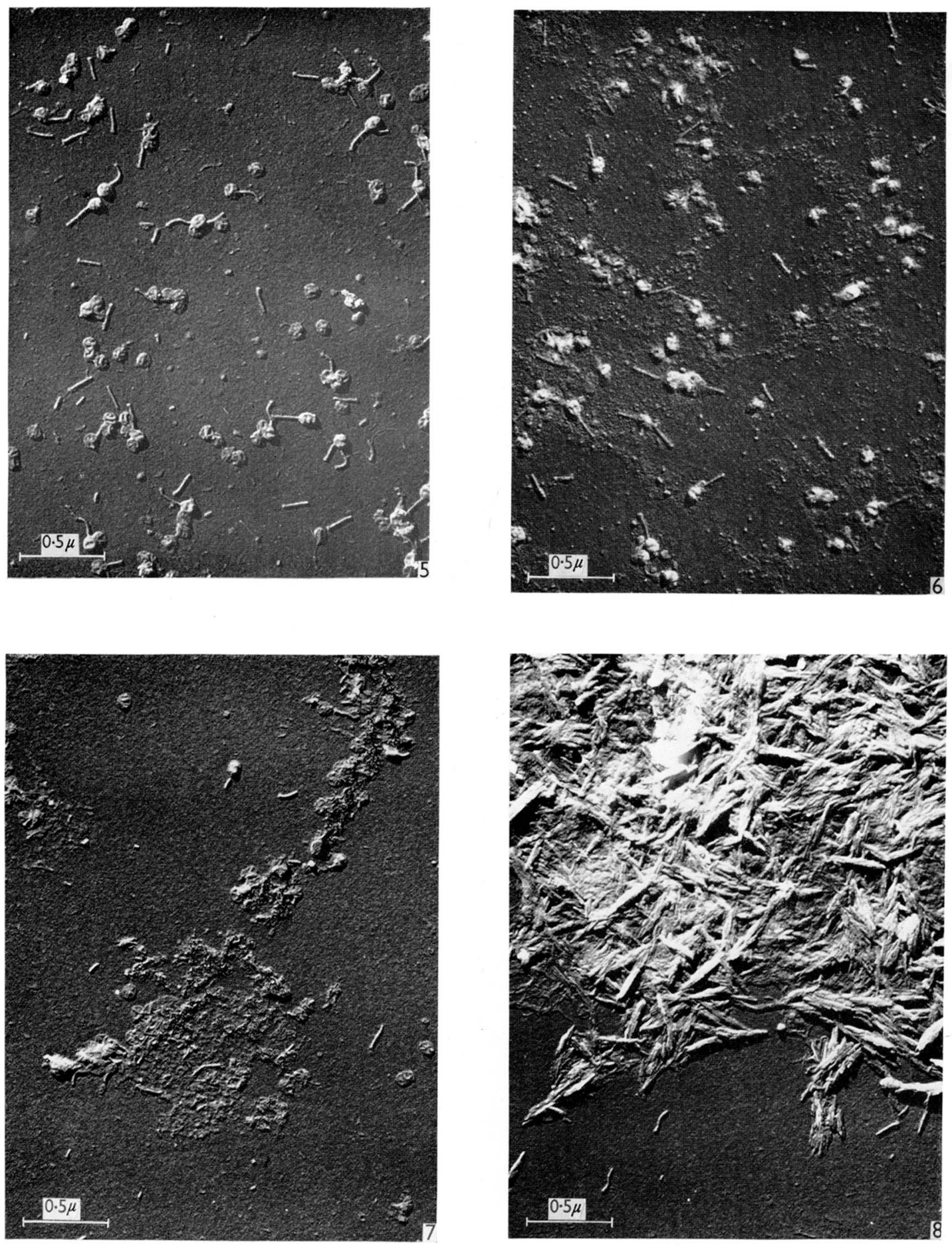

D. L. ANDERSON AND S. G. BRADLEY 